\title{
Kendala Dalam Pelaksanaan Kegiatan Pramuka Di Masa Pandemi Covid-19
}

\author{
Annisa Lassura \\ Pendidikan Luar Sekolah, Fakultas Ilmu Pendidikan, Universitas Negeri Padang \\ annisalassura23@gmail.com
}

Received: 18 Juni 2021; Revised: 18 Juni 2021; Accepted: 29 Juni 2021

\begin{abstract}
Schools become a national education because education is also an effort to prepare students through guidance, teaching, and or training activities for their roles in the future. Scout extracurricular is a mandatory curriculum in education as a pillar of national character education. This research is to find out what obstacles exist in the extra-curricular scouts. Students will gain direct experience and be able to find their own various knowledge that he learns. Therefore, one of the factors for the development of religious character, depending on the educational process received, in this case is extracurricular activities. Thus, through extracurricular activities, it is hoped that religious characters can be embedded in the souls of students, so that they become individuals of faith and dignity.
\end{abstract}

Keywords: Education, Extracurricular, Scouts.

\begin{abstract}
ABSTRAK
Sekolah menjadi salah satu pendidikan nasional karena pendidikan juga menjadi salah satu usaha untuk menyiapkan peserta didik melalui kegiatan bimbingan, pengajaran, dan latihan bagi peranannya di masa yang akan datang. Ekstrakurikuler Pramuka menjadi kurikulum wajib pada pendidikan sebagai pilar pendidikan karakter bangsa. Penelitian ini untuk mengetahui kendala apa saja yang ada didalam ekstrakurikuler pramuka. Peserta didik akan memperoleh pengalaman langsung serta dapat terlatih untuk menemukan sendiri berbagai pengetahuan yang ia pelajari. Oleh karena itu, salah satu faktor adanya perkembangan karakter religius, tergantung pada proses pendidikan yang diterima, dalam hal ini adalah kegiatan ekstrakulikuler. Dengan demikian, melalui kegiatan ekstrakulikuler diharapkan karakter religius dapat tertanam ke dalam jiwa peserta didik, sehingga menjadi pribadi yang beriman dan bermartabat.
\end{abstract}

Kata kunci: Pendidikan, Ekstrakurikuler, Pramuka.

(C)2021 Annisa Lassura Under the license CC BY-SA 4.0

\section{PENDAHULUAN}

Menurut Undang-Undang No 20 tahun 2003 pasal 1 tentang Sistem Pendidikan Nasional, "Pendidikan adalah usaha sadar dan terencana untuk mewujudkan suasana belajar dan proses pembelajaran agar peserta didik secara aktif mengembangkan potensi dirinya untuk memiliki kekuatan spiritual, keagamaan, pengendalian diri, kecerdasan akhlak mulia serta keterampilan yang diperlukan dirinya." Pendidikan memiliki peran penting bagi kelangsungan 
kehidupan manusia karena pendidikan dapat membuat orang cerdas, kreatif, bertanggung jawab dan produktif.

Pendidikan menjadi faktor yang berpengaruh dalam kehidupan individu karena melalui pendidikan individu dapat meningkatkan kecerdasan, keterampilan, mengembangkan diri, membentuk kepribadian yang baik, bertanggung jawab, dan kreatif. Hal tersebut sejalan dengan tujuan pendidikan nasional yaitu untuk mengembangkan potensi yang dimiliki peserta didik agar menjadi manusia yang beriman dan bertakwa kepada Tuhan yang Maha Esa, berakhlak mulia, berilmu, cakap, kreatif, mandiri, dan menjadi warga negara yang demokratis serta bertanggung jawab.

Salah satu wadah untuk mencapai tujuan pendidikan nasional adalah sekolah. Sekolah merupakan sebuah lembaga pendidikan yang bertanggung jawab untuk memberikan berbagai pengetahuan dan keterampilan, membentuk karakter, serta mengembangkan berbagai nilai dan sikap baik melalui pendidikan formal maupun pendidikan non formal. Pengembangan potensi peserta didik sebagaimana dimaksud dalam tujuan pendidikan nasional dapat diwujudkan melalui kegiatan ekstrakurikuler.

Kegiatan ekstrakurikuler memiliki peranan penting dalam pembelajaran di sekolah khususnya dalam mencapai tujuan pendidikan nasional. Ektrakurikuler merupakan kegiatan yang diselenggarakan oleh pihak sekolah di luar jam sekolah guna memberikan pengaruh yang positif terhadap pembentukan kepribadian peserta didik. Menurut Joko (2010:26), bahwa ekstrakurikuler adalah salah satu perangkat operasional (supplement and complements) dalam kurikulum pendidikan nasional.

Diadakannya kegiatan ekstrakurikuler di luar sekolah agar peserta didik dapat meningkatkan kemampuannya mengenai pembelajaran yang akan atau telah dilakukannya dalam intrakurikuler, serta juga sebagai wadah dalam menyalurkan minat dan bakat peserta didik, serta membantu mewujudkan pembentukan kepribadian yang baik bagi peserta didik. Di samping itu, kedudukan ekstrakurikuler dalam sistem kurikulum nasional tidak hanya sebagai pengisi waktu luang, tetapi sebagai komplemen kurikulum yang dirancang secara 
terstruktur dan sistematis, serta relevan sebagai upaya dalam meningkatkan mutu pendidikan nasional di sekolah.

Melalui kegiatan ekstrakurikuler inilah pembinaan dan pengembangan bakat dan minat peserta didik sebagai bagian yang tidak terpisahkan bagi generasi muda yang diupayakan dan direalisasikan di sekolah. Pengembangan ekstrakurikuler dinilai dapat bermanfaat bagi sekolah sebagai sarana untuk promosi kepada masyarakat.

Ekstrakurikuler mencakup berbagai kegiatan yang bisa dilakukan di luar jam sekolah seperti olahraga, seni dan musik, paskibraka, pramuka, dan lain- lain. Tetapi, ekstrakurikuler yang paling banyak dapat menciptakan, mengembangkan, dan mencapai kepribadian peserta didik adalah ekstrakurikuler pramuka.

Pramuka diatur dalam Undang-Undang Nomor 12 Tahun 2010 tentang Gerakan Pramuka, yang menyebutkan bahwa Gerakan pramuka adalah sebuah organisasi yang dibentuk oleh pramuka untuk menyelenggarakan pendidikan kepramukaan. Pramuka adalah warga negara Indonesia yang ikut berperan aktif dalam pendidikan kepramukaan serta mengamalkan Satya Pramuka dan Darma Pramuka.

Kepramukaan adalah segala aspek yang berkenaan dengan pramuka. Oleh karena itu, pendidikan kepramukaan merupakan sebuah proses untuk membentuk kepribadian, kecakapan hidup, dan akhlak mulia melalui penghayatan dan pengamalan nilai-nilai kepramukaan.

Menurut Notoatmodjo (2007) bahwa setiap peserta didik memiliki kepribadian, watak dan sikap yang berbeda. Hal ini ditunjukan dengan perilaku peserta didik dalam menyikapi rangsangan dari luar yang didukung dengan pendapat skinner. Lebih lanjut, Notoatmodjo (2007) menambahkan bahwa respon terhadap stimulus tersebut dipengaruhi oleh faktor-faktor internal dan eksternal yang dapat berupa sifat bawaan seperti lingkungan fisik, budaya, sosial, ekonomi, politik dan lain-lain.

Pendidikan kepramukaan dalam Sistem Pendidikan Nasional termasuk dalam jalur pendidikan non formal yang diselenggarakan dengan penanaman nilai-nilai gerakan pramuka dalam pembentuan kepribadian yang berakhlak mulia, 
berjiwa patriotisme, taat hukum, disiplin, menjunjung tinggi nilai-nilai luhur bangsa, dan memiliki kecakapan hidup. Gerakan pramuka selaku penyelenggara pendidikan kepramukaan mempunyai peran yang besar dalam pembentukan karakter kepribadian generasi muda sehingga memiliki pengendalian diri dan kecakapan hidup untuk menghadapi tantangan sesuai dengan tuntutan perubahan kehidupan lokal, nasional maupun global.

Eksistensi pokok gerakan pramuka yang sebagaimana tercantum dalam RUU Gerakan Pramuka, setidaknya terdapat lima hal pokok yang menjadi dasar kegiatan kepramukaan, yaitu: (1) penetapan Pancasila sebagai sumber nilai pendidikan kepramukaan, (2) penetapan Gerakan Pramuka sebagai satu- satunya wadah otonom yang bertanggungjawab dalam penyelenggaraan pendidikan pramuka, (3) penetapan APBN/APBD sebagai bagian dari sumber dana gerakan pramuka, (4) penetapan pertanggungjawaban kepengurusan kepada Presiden Republik Indonesia sebagai pramuka utama, dan (5) sebagai unsur pokok dalam sistem pendidikan kepramukaan.

Menurut Undang-Undang Nomor 12 Tahun 2010, bahwa tujuan gerakan pramuka adalah untuk membentuk setiap pramuka agar mempunyai kepribadian yang beriman, bertakwa, berakhlak mulia, berjiwa patriotik, taat hukum, disiplin, menjunjung tinggi nilai-nilai luhur bangsa dan memiliki kecakapan hidup sebagai kader bangsa dalam menjaga dan membangun Negara Kesatuan Republik Indonesia, mengamalkan Pancasila serta melestarikan lingkungan hidup.

Kegiatan yang dilakukan oleh anggota pramuka dapat berupa berkemah, menjelajah, baris berbaris, api unggun, diskusi dan masih banyak kegiatan yang dapat membentuk kepribadian yang berkarakter. Kegiatan pramuka bukan hanya sekedar kegiatan berpetualang, melainkan juga terdapat pemberian materi-materi yang berguna sebagai bekal bagi setiap anggota pramuka seperti pertolongan pertama pada gawat darurat (PPGD), semaphore, morse, dan lain- lain. Hal tersebut juga tercantum dalam Undang-Undang Nomor 12 Tahun 2010 Pasal 8, yaitu: (1) keimanan dan ketakwaan kepada Tuhan yang Maha Esa, (2) kecintaan pada alam dan sesama manusia, (3) kecintaan pada tanah air dan bangsa, (4) kedisiplinan, keberanian, dan kesetiaan, (5) tolong menolong, (6) 
bertanggungjawab dan dapat dipercaya, (7) jernih dalam berfikir, berkata, dan berbuat, (8) hemat, cermat dan bersahaja, dan (9) rajin dan terampil.

Salah satu sekolah yang menyelenggarakan kegiatan ekstrakurikuler kepramukaan adalah SMA Al-Istiqamah yang terletak di Kabupaten Pasaman Barat. Gugus depan yang diberi nama di SMA Al-Istiqamah adalah Gudep Jaya Atas Istiqamah 01.111-01-081. Ekstrakurikuler di SMA Al-Istiqamah menjadi salah satu kegiatan ekstrakurikuler yang banyak diminati jika dibandingkan dengan kegiatan ekstrakurikuler lainnya seperti paskibraka dan palang merah remaja (PMR).

Kegiatan rutin yang dilakukan di Gudep Jaya Atas Istiqamah adalah pengambilan bintara, the game of JAI, pengambilan TKK, latihan gabungan, buka bersama, MOP, penghijauan, pengukuhan, dan camping. Kegiatan- kegiatan tersebut dilaksanakan setiap tahun yang telah ditetapkan oleh pengurus dewan ambalan bersama dengan pembina ekstrakurikuler pramuka di SMA AlIstiqamah. Masing-masing kegiatan mempunyai tujuan penting yang dapat berpengaruh terhadap perilaku peserta didik sebagai anggota pramuka, seperti kedisiplinan, kesopanan, kejujuran, saling menghargai, nasionalisme, patriotisme, bertakwa, dan berakhlak mulia.

Seiring dengan maraknya pandemi coronavirus disease-19 yang sudah mewabah ke Indonesia sejak Maret 2020, dan telah menyebar luas ke seluruh wilayah Indonesia termasuk Sumatra Barat, khususnya Pasaman Barat membuat kegiatan ekstrakurikuler pramuka di SMA Al-Istiqamah menjadi terganggu, namun demikian kegiatan kepramukaan tetap berjalan walaupun beberapa kegiatan ditiadakan, dan tetap mematuhi protokol kesehatan.

Berdasarkan hasil survey yang telah penulis lakukan tertanggal 28 Mei 2021 di SMA Al-Istiqamah Pasaman Barat, diperoleh hasil bahwa, kegiatan kepramukaan di sekolah tetap berjalan sebagaimana semestinya, namun terdapat beberapa kegiatan yang ditiadakan seperti camping, the game of JAI, dan lain-lain. Selain itu, setiap kegiatan yang dilakukan tetap memperhatikan protokol kesehatan ketat yang dianjurkan oleh Kementerian Kesehatan Republik Indonesia. 
Selain ditiadakannya beberapa kegiatan dan tetap dijalankannya beberapa kegiatan, walaupun dengan memperhatikan protokol kesehatan, beberapa orang tua peserta didik tidak mengizikan anaknya untuk mengikuti kegiatan ekstrakurikuler pramuka sehabis jam sekolah intrakurikuler dengan berbagai macam alasan, salah satunya adalah orang tua peserta didik takut anaknya terpapar coronavirus disease-19 sehingga orang tua tidak ingin mengambil risiko yang lebih jauh. Oleh karena itu, pihak sekolah terkhusus ekstrakurikuler pramuka tidak mewajibkan anggota pramuka mengikuti kegiatan kepramukaan, namun hanya diikuti oleh peserta didik yang sudah memperoleh izin dari orang tua. Selain itu, juga terdapat permasalahan lain yaitu: (1) kurangnya pembina pramuka di SMA Al-Istiqamah Kabupaten Pasaman Barat, sehingga pelaksanaannya juga menjadi kurang efektif terlihat pembina pramuka dan jumlah peserta yang mengikuti kegiatan ekstrakurikuler pramuka tidak seimbang, dan (2) kegiatan kepramukaan di SMA Al-Istiqamah belum terstruktur dengan baik.

Menurut David A.N, dkk, (dalam Khaerul Umam, 2010), bahwa prinsipprinsip dasar manusia berperilaku terdapat perbedaan, yaitu: (1) manusia berbeda perilakunya karena kemampuannya tidak sama, (2) manusia mempunyai kebutuhan yang berbeda, (3) orang berpikir tentang masa depan dan membuat pilihan tentang bertindak, (4) seseorang memahami lingkungannya dalam hubungannya dengan pengalaman masa lalu dan kebutuhannya, (5) seseorang mempunyai reaksi-reaksi senang atau tidak senang (affective), dan (6) banyak faktor yang menentukan sikap dan perilaku seseorang.

Melalui kegiatan kepramukaan diharapkan peserta didik dapat membentuk kepribadian dan jiwa kepemimpinan yang dapat menjadi contoh bagi peserta didik lainnya, baik di lingkungan sekolah maupun lingkungan bermasyarakat, berbangsa dan bernegara. Selain itu, memiliki kemampuan untuk berkarya dengan semangat kemandirian, kebersamaan, kepedulian, tanggung jawab, dan berani menghadapi berbagai tugas. 


\section{METODE}

Pendekatan yang digunakan pada penelitian ini adalah pendekatan deskriptif kualitatif. Menurut Lincoln dan Guba (dalam Moleong, 2014:11), bahwa salah satu ciri penelitian kualitatif adalah deskriptif, yang berarti data yang dikumpulkan berupa kata-kata, gambar, dan bukan angka-angka. Sejalan dengan itu, menurut Darmawan (2014:217), bahwa pendekatan kualitatif adalah pendekatan penelitian yang digunakan untuk meneliti di lapangan atas hal-hal yang sedang terjadi. Data dalam penelitian berasal dari hasil wawancara, dokumentasi, dan observasi.

Menurut Moleong (2014:6), bahwa penelitian kualitatif merupakan penelitian yang bertujuan memahami fenomena yang terjadi di lapangan seperti perilaku, persepsi, motivasi, dan lan-lain baik secara holistik maupun dengan memanfaatkan berbagai metode secara ilmiah. Selain itu, menurut Sugiyono (2017:15), bahwa pendekatan penelitian kualitatif merupakan suatu pendekatan penelitian yang berlandaskan filsafat positivisme yang digunakan dalam meneliti objek yang alamiah dimana peneliti akan bertindak sebagai instrumen kunci, pengambilan sampel dilakukan secara purposive dan snowball, teknik pengumpulan data dengan triangulasi (gabungan) yang bersifat induktif/kualitatif dan hasil metode penelitian ini menegaskan pada makna daripada generalisasi. Prosedur pengumpulan data dalam penelitian ini adalah: (1) wawancara, wawancara yang digunakan dalam penelitian ini adalah wawancara secara tidak terstruktur. Pada pengumpulan data dengan wawancara, penulis melakukan wawancara dengan kepala sekolah, guru, pembina pramuka, dan peserta didik, (2) observasi, observasi digunakan mengamati secara langsung mengenai pelaksanaan ekstrakurikuler pramuka, dan (3) dokumentasi, dokumentasi digunakan untuk menggali data mengenai pelaksanaan ekstrakurikuler pramuka.

Teknik analisis data yang digunakan dalam penelitian ini adalah teknik analisis data secara interaktif. Pada penelitian ini, teknik analisis data secara interaktif mengacu pada model yang diterapkan oleh Miles dan Huberman (dalam Sugiyono, 2013:91), bahwa tiga komponen analisis secara interaktif, yaitu: (1) Reduksi data, kegiatan ini dilakukan dengan mengumpulkan data-data kasar yang 
diambil secara langsung di lapangan dari hasil wawancara dengan subyek penelitian serta pengamatan secara langsung, (2) Sajian data, data disajikan dalam bentuk narasi yang dimulai dari langkah awal penelitian hingga akhir kegiatan penelitian, dan (3) Penarikan kesimpulan, berisikan kesimpulan berdasarkan data yang telah diproses melalui reduksi data dan penyajian data. Penarikan kesimpulan ini bersifat sementara dan akan berubah apabila tidak ditemukannya bukti yang kuat atau yang mendukung pada tahap pengumpulan data selanjutnya. Namun, apabila kesimpulan yang dikemukakan pada tahap awal telah mendapatkan bukti yang valid dan konsisten terjun ke lapangan dalam mengumpulkan data maka kesimpulan yang telah dikemukakan tersebut merupakan kesimpulan yang valid atau credible. Teknik uji keabsahan data yang digunakan yaitu triangulasi dengan sumber dari member check (Sugiyono, 2015:239).

Model interaktif dalam analisis data ini mengacu pada Miles dan Huberman (2009:16-21) yang dapat dilihat pada Gambar 1 di bawah ini:

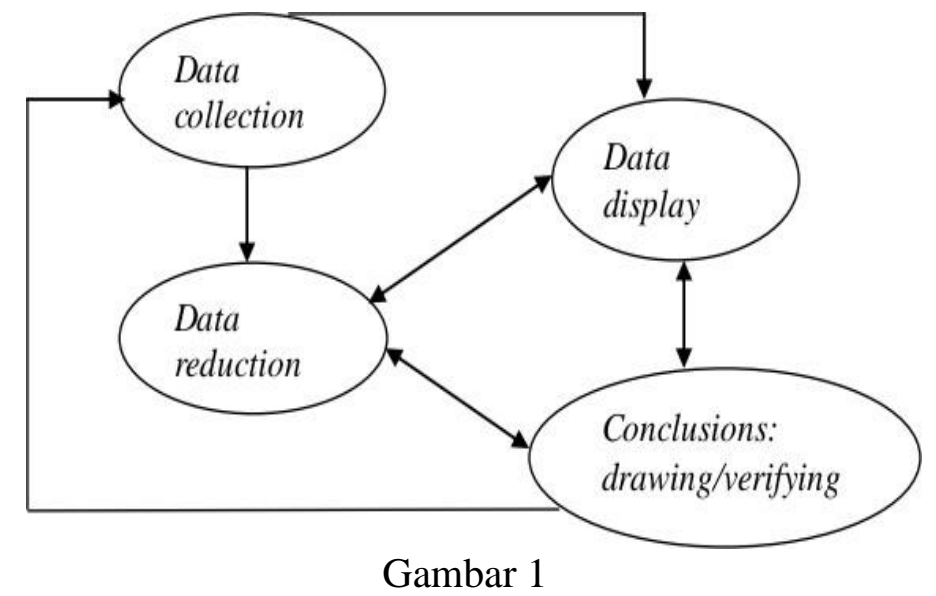

Komponen-Komponen Analisis Data (Interactive Model)

\section{HASIL DAN PEMBAHASAN}

\section{Hasil}

Berdasarkan hasil temuan di lapangan bahwa pada masa pandemi coronavirus disease-19 kegiatan kepramukaan di SMA Al-Istiqamah dilakukan dengan mematuhi protokol kesehatan, dan menimbulkan beberapa kendala dalam 
pelaksanaan ekstrakurikuler pramuka di SMA Al-Istiqamah. Berikut ini beberapa kendala dalam pelaksanaannya, yaitu:

Pertama, Pembina Pramuka yang jarang hadir untuk mendampingi anggota pramuka saat kegiatan latihan cukup menghambat pembentukan perilaku disiplin anggota pramuka. Ketidakhadiran Pembina dalam latihan mingguan membuat anggota pramuka menjadi kurang termotivasi dalam melaksanakan kegiatan kepramukaan. Tidak hadirnya Pembina dalam kegiatan kepramukaan belum mendapatkan jawaban yang pasti, karena pada saat dihubungi Pembina pramuka susah untuk dihubungi. Selain itu, hal ini juga dipastikan akibat dari adanya pandemi coronavirus disease-19 yang membuat Pembina Pramuka tidak hadir dalam pelaksanaan kegiatan pramuka dan takut terdampak virus tersebut. Padahal di lapangan kegiatan tetap mematuhi protokol kesehatan, dan Pembina hanya sebagai pengontrol dalam kegiatan pramuka bukan sebagai pelaksana. Oleh sebab itulah, kegiatan pramuka menjadi terkendala dan peserta didik ekstrakurikuler menjadi slow motivation dalam melaksanakan kegiatan. Walaupun demikian, kegiatan kepramukaan tetap berlanjut dan berjalan dengan baik.

Kedua, kekurangan pendanaan dalam pelaksanaan kegiatan pramuka yang menghambat proses pembentukan kedisiplinan anggota pramuka. Hal tersebut sangat jelas menghambat jalannya kegiatan pramuka, karena dalam pelaksanannya pendanaan menjadi faktor yang sangat penting guna kelancaran jalannya kegiatan. Namun, hal tersebut menjadi kendala yang berarti di SMA Al-Istiqamah Kabupaten Pasaman Barat. Berdasarkan hasil wawancara, dan pengamatan secara langsung di sekolah, diperoleh hasil bahwa kekurangan dana kegiatan kepramukaan di SMA Al-Istiqamah disebabkan oleh berbagai faktor, diantaranya yaitu: kuranganya komunikasi antara kwartir ranting dengan gugus depan, kemampuan ilmu kepramukaan yang masih terbatas, pembina tidak memiliki pengembangan kreativitas, alokasi dana yang sedikit untuk pendidikan non formal khususnya kepramukaan, dan pangkalan yang kurang responsif terhadap perkembagan kondisi gugus depannya. 
Faktor-faktor penyebab diatas dapat diperjelas sebagai berikut:

1. Kurangnya komunikasi antara kwartir ranting dengan gugus depan Kendala ini disebabkan karena hubungan yang kurang baik antara satu sama lainnya, keduanya belum akrab dan belum menjalin komunikasi secara lancar baik di dalam kegiatan maupun di luar kegiatan, sehingga dalam hal pengambilan kebijakan keduanya seringkali berbeda keputusan.

2. Kemampuan ilmu kepramukaan masih terbatas

Kemampuan yang dimiliki oleh ketua kepramukaan di SMA Al-Istiqamah masih cukup terbatas, karena kurangnya wadah dalam mendapatkan informasi kepramukaan di Pasaman Barat. Selain itu, kurangnya mengikuti seminar kepramukaan dan lain sebagainya.

3. Pembina yang tidak memiliki pengembangan kreativitas

Disamping jarang hadir dalam kegiatan kepramukaan, pembina juga tidak memiliki pengembangan kreativitas dalam kepramukaan di SMA AlIstiqamah, sehingga kegiatan yang itu-itu saja selalu berulang, dan dapat menimbulkan kebosanan terhadap peserta didik dalam ekstrakurikuler pramuka.

4. Alokasi dana yang sedikit untuk kegiatan ekstrakurikuler kepramukaan Maraknya pandemi coronavirus disease-19 membuat perekonomian terancam melemah, oleh sebabnya dana di SMA Al-Istiqamah menjadi turun, sehingga alokasi dana menjadi tidak lancar.

5. Pangkalan yang kurang responsif terhadap perkembangan kondisi gugus depan Kondisi ini menyebabkan belum adanya perkembangan yang baik dalam ekstrakurikuler kepramukaan di SMA Al-Istiqamah, sehingga organisasi kepramukaan belum dapat berkembang mengikuti teknologi, dan belum dapat bersaing dengan organisasi kepramukaan secara nasional khususnya dengan sekolah yang ada di Kabupaten Pasaman Barat.

Ketiga, anggota pramuka yang belum disiplin yaitu jarang menghadiri kegiatan kepramukaan dalam latihan rutin mingguan pramuka. Adanya faktor internal dan faktor eksternal mempengaruhi kedisiplinan peserta didik. Adapun faktor internal yang mempengaruhinya yaitu rasa malas untuk latihan 
kepramukaan akibat pandemi coronavirus disease-19. Sedangkan faktor eksternal adalah pengaruh lingkungan terutama lingkungan teman sebaya dan keluarga.

Faktor internal, rasa malas untuk latihan kepramukaan sebagai akibat adanya pandemi coronavirus disease-19 yang membuat semua pihak menjadi khawatir terkena virus tersebut. Akibatnya, muncul rasa malas bagi peserta didik ekstrakurikuler kepramukaan untuk menghadiri kegiata, namun juga tidak semua peserta didik yang tidak hadir ada juga peserta didik yang semangat dalam melaksanakan kegiatan kepramukaan. Faktor eksternal, adanya pengaruh lingkungan, misalnya lingkungan teman sebaya, dengan adanya teman yang tidak hadir saat pelaksanaan kegiatan ekstrakurikuler kepramukaan mengakibatkan peserta didik lainnya untuk juga tidak ikut pada kegiatan kepramukaan, sehingga hal ini ditiru oleh beberapa peserta didik lainnya. Selain itu, juga adanya pengaruh dari keluarga terutama orang tua yang tidak mengizinkan anaknya untuk mengikuti kegiatan kepramukaan karena maraknya kasus coronavirus disease-19 di Kabupaten Pasaman Barat.

Keempat, masih terdapat beberapa anggota ekstrakurikuler kepramukaan yang melanggar tata tertib ekstrakurikuler kepramukaan ataupun tata tertib sekolah SMA Al-Istiqamah. Disiplin menjadi kunci penting dalam pembentukan karakter dan perilaku peserta didik menjadi lebih baik. Sekolah menjadi wadah bagi peserta didik dalam membentuk karakter disamping bertugas utama untuk mencerdaskan anak bangsa. Oleh karenanya, disiplin dapat diperoleh dengan mengikuti kegiatan ekstrakurikuler kepramukaan.

Faktor yang menyebabkan anggota kepramukaan melanggar tata tertib sekolah atau ekstrakurikuler kepramukaan adalah ditinjau dari faktor internal dan eksternal. Faktor internal yang menyebabkan adalah faktor biologis peserta didik, dimasa peralihan dari ramaja menuju dewasa membuat perilaku peserta didik menjadi labil dan tidak konsisten. Hal ini membuat peserta didik berperilaku berubah-ubah sesuai dengan kondisi dilingkungannya. Selain itu, peserta didik masih mencari jati diri yang sebenarnya untuk menjadi pribadi yang dewasa sesuai dengan yang sebenarnya. Faktor eksternal yang menyebabkan adalah faktor lingkungan tempat peserta didik berada. Faktor lingkungan memberikan pengaruh 
yang besar terhadap perilaku peserta didik. Oleh karena itu, faktor lingkungan yang baik dinilai menciptakan perilaku yang baik pula terhadap peserta didik atau individu dan sebaliknya.

Kelima, sulitnya orang tua dalam memberikan izin kepada anaknya untuk menjadi pengurus inti ekstrakurikuler kepramukaan. Hal ini dapat dilihat dari banyaknya orang tua yang masih belum memercayakan anaknya untuk menjadi anggota inti kepramuaan. Hal tersebut disebabkan karena ketakutan orang tua melihat anaknya sibuk dalam ekstrakurikuler kepramukaan, apabila di tengah pandemi coronavirus disease-19 saat ini membuat ketakutan orang tua peserta didik menjadi lebih meningkat.

\section{Pembahasan}

Pembina pramuka yang jarang menghadiri kegiatan ekstrakurikuler kepramukaan untuk mendampingi anggota pramuka saat kegiatan latihan menghambat pembentukan kepribadian perilaku disiplin anggota. Ketidakhadiran pembina dalam latihan rutin setiap minggu juga membuat para anggota ekstrakurikuler kepramukaan menjadi kurang termotivasi dalam melaksanakan kegiatan kepramukaan. Hal tersebut menunjukkan bahwa tidak disiplinnya pembina pramuka membawa pengaruh yang tidak baik kepada anggota kepramukaan, serta menjadi contoh bagi anggota kepramukaan untuk mengikuti perbuatan pembina pramuka di SMA Al-Istiqamah Kabupaten Pasaman Barat. Berdasarkan hasil wawancara dan observasi penulis di lapangan menunjukkan bahwa pembina pramuka jarang hadir dalam latihan rutin mingguan pramuka di SMA Al-Istiqamah Pasaman Barat.

Pembina pramuka yang jarang menghadiri kegiatan kepramukaan dapat diminimalisir dengan upaya melakukan rapat umum antar sesama kepengurusan kepramukaan di SMA Al-Istiqamah Kabupaten Pasaman Barat guna mencari jalan keluar atas kendala tersebut, seperti duduk bersama, agar pelaksanaan kegiatan rutin mingguan dapat dihadiri oleh pembina atau dapat pula dengan mengganti hari kegiatan ekstrakurikuler pada hari pembina pramuka dapat menghadiri kegiatan. 
Kekurangan dana dapat disebabkan berbagai faktor seperti kurangnya komunikasi antara kwartir ranting dengan gugus depan, kemampuan ilmu kepramukaan yang terbatas, pembina tidak memiliki pengembangan kreativitas, alokasi dana yang sedikit untuk pendidikan non formal khususnya ekstrakurikuler kepramukaan, dan pangkalan yang kurang responsif terhadap perkembangan kondisi gugus depannya. Berdasarkan hasil wawancara dan pengamatan secara langsung di lapangan, penulis memperoleh hasil bahwa masih adanya kekurangan pendanaan dalam Gugus Depan Pramuka SMA Al- Istiqamah karena bantuan dana dari Pemerintah Daerah, BOS, dan kas anggota belum mampu mencukupi kebutuhan pendanaan kegiatan pramuka. Hal ini juga didasari karena adanya pandemi coronavirus disease-19 yang membuat sulitnya memperoleh pendanaan dari berbagai pihak baik internal maupun eksternal. Oleh sebab itu, kegiatan kepramukaan di SMA Al-Istiqamah dilakukan dengan kesederhanaan, namun tetap sesuai dengan prinsip standar kepramukaan secara nasional.

Kurangnya dana dalam kegiatan kepramukaan dapat diminimalisir dengan konsistensi pembayaran uang kas setiap anggota, dengan adanya pandemi coronavirus disease-19 ekstrakurikuler pramuka tetap bisa melakukan kegiatan dengan menurunkan biaya pembayaran uang kas yang semula Rp. 2.000,- per hari dapat diganti dengan Rp1.000,- per hari. Hal tersebut dapat menjadi upaya dalam mencukupkan dana kepramukaan agar kegiatan dapat berjalan dengan lancar.

Anggota pramuka yang belum disiplin yaitu jarang menghadiri kegiatan latihan rutin secara mingguan pramuka. Hal tersebut dipengaruhi karena adanya faktor internal dan eksternal. Berdasarkan hasil wawancara dan pengamatan secara langsung di lapangan, penulis memperoleh hasil bahwa anggota pramuka yang tidak datang latihan pramuka disebabkan karena berbagai alasan seperti sakit, les/bimbel, dan kegiatan lainnya. Faktor internal yaitu kurangnya kesadaran, motivasi, dan lain-lain. Sedangkan faktor eksternal adalah Faktor lingkungan bermain, faktor lingkungan sekitar, dan lain-lain.

Kedisiplinan menjadi hal yang penting dalam membentuk karakter perilaku siswa yang lebih baik. Sekolah menjadi satu-satunya tempat yang positif dalam membentuk perilaku peserta didik, disamping sebagai tugas utama dalam 
mencerdaskan kehidupan bangsa. Di sekolah dibentuk adanya kegiatan ekstrakurikuler yang berguna dalam membentuk dan mengembangkan minat dan bakat peserta didik, pembentukan karakter yang baik, dan menciptakan peserta didik yang berperilaku sesuai dengan akhlak yang mulia.

Berdasarkan hasil wawancara dan pengamatan secara langsung di lapangan, penulis memperoleh hasil bahwa masih ada beberapa anggota kepramukaan yang melanggar tata tertib sekolah seperti terlambat, tidak hadir, dan keluar masuk kelas saat pembelajaran sedang berlangsung. Anggota tersebut adalah anggota kepramukaan yang tidak displin dalam menaati tata tertib peraturan sekolah, tidak disiplin dalam waktu, dan sikap.

Orang tua kadang-kadang sulit untuk memberikan izin kepada anaknya dalam menjadi pengurus inti ekstrakurikuler kepramukaan di SMA Al- Istiqamah. Menurut Sri (2011:199), Faktor sikap orang tua mempengaruhi perilaku anak dalam melakukan sesuatu. Sejalan dengan itu, menurut Fatah (2011:130), bahwa salah satu faktor yang dapat mendukung keberhasilan pendidikan yaitu lingkungan.

Berdasarkan pendapat ahli di atas, bahwa lingkungan keluarga terkhusus orang tua menjadi faktor yang berpengaruh dalam pendidikan anak. Faktor lingkungan keluarga mempengaruhi kedisiplinan anak di sekolah maupun di lingkungan bermasyarakat. Berdasarkan hasil pengamatan langsung di lapangan, diperoleh hasil bahwa orang tua yang tidak memberikan izin kepada anaknya untuk menjadi pengurus inti kepramukaan SMA Al-Istiqamah memiliki berbagai alasan, seperti pramuka membuat anaknya menjadi sibuk sehingga lupa untuk belajar, lupa membuat tugas sekolah, lupa menjaga kesehatan, karena jadwal kegiatan yang cukup padat. Pada dasarnya, kegiatan ekstrakurikuler kepramukaan memiliki banyak manfaat bagi peserta didik untuk mencapai kehidupan yang lebih baik dari sekarang dan masa depan agar selalu menanamkan nilai-nilai kedisiplinan di lingkungan sekitar. 


\section{SIMPULAN}

Berdasarkan hasil pembahasan di atas, maka dapat disimpulkan bahwa kendala dalam pelaksanaan kegiatan ekstrakurikuler kepramuakaan pada masa pandemi coronavirus disease-19 di SMA Al-Istiqamah dalam membentuk perilaku disiplin peserta didik yaitu:

1. Pembina pramuka jarang menghadiri kegiatan kepramukaan untuk memberikan pengawasan kepada anggota kepramukaan dalam melaksanakan kegiatan latihan pramuka, sehingga dapat menghambat pembentukan perilaku disiplin anggota ekstrakurikuler kepramukaan.

2. Kurangnya pendanaan dalam melaksanakan kegiatan kepramukaan sehingga menghambat proses pembentukan perilaku disiplin anggota ekstrakurikuler kepramukaan.

3. Anggota kepramukaan belum disiplin dan jarang menghadiri kegiatan latihan rutin mingguan ekstrakurikuler kepramukaan.

4. Masih terdapat beberapa anggota kepramukaan yang melanggar tata tertib peraturan sekolah.

5. Orang tua tidak memberikan izin kepada anaknya untuk menjadi pengurus inti ekstrakurikuler kepramukaan

\section{DAFTARPUSTAKA}

Darmawan, Deni. (2014). Metode Penelitian kualitatif. Bandung: PT: Remaja Rosdakarya.

Moleong, J. (2014). Metode Penelitian Kualitatif. Bandung: Remaja Rosdakarya. Miles, Matthew B. \& A. Michael Huberman. (2009). Analisis Data Kualitatif. Jakarta: UI-Press.

Minarti, Sri. (2011). Manajemen Sekolah Mengelola Lembaga Pendidikan Secara Mandiri. Yogyakarta: Ar Ruzz Media.

Muritho, Joko. (2010). Kursus Mahir Dasar untuk Pembina Pramuka. Kolonprogo: Kwarcab Kulon Progo.

Notoatmodjo, S. (2007). Promosi Kesehatan dan Ilmu Perilaku. Jakarta: Rineka Cipta. 
Sugiyono. (2013). Metode Penelitian Kuantitatif Kualitatif dan R\&D. Bandung: Alfabet.

Sugiyono. (2017). Metode Penelitian Kuantitatif Kualitatif dan R\&D. Bandung: Alfabeta.

Umam, Khaerul. (2010). Perilaku Organisasi. Bandung: Pustaka Setia. UndangUndang Republik Indonesia Nomor 12 Tahun 2010 tentang Gerakan Pramuka.

Undang-Undang Republik Indonesia Nomor 20 Tahun 2003 tentang Sistem Pendidikan Nasional.

Undang-Undang Republik Indonesia Nomor 12 Tahun 2010 tentang Gerakan Pramuka.

Yasin, Fatah. (2011). Penumbuhan Kedisiplinan Sebagai Pembentukan Karakter Peserta Didik di Madrasah. Jurnal Edukasi (Vol 9). 